\title{
Artist as visionary
}

\author{
Norval Morrisseau: Shaman Artist \\ Curator Greg Hill \\ National Gallery of Canada \\ Until Apr. 30, 2006
}

$\mathrm{N}$ orthrop Frye, the venerable commentator on Canadian culture, postulated that the dominant Canadian concern is not "Who am I?" but rather "Where is here?" ${ }^{1}$ Although this is an obvious question for immigrants who are newly arrived to this hostile landscape, theoretically this wouldn't be the case for Aboriginal peoples given their profound connection to the land through legends and lore. But their culture has been threatened, even shattered, by colonialism, and so in an odd way, they are faced with the same question as their oppressors: Where is here? And the corollary: What is my place here?

The answer, as witnessed in the exhibit Norval Morrisseau: Shaman Artist, lies in, first, reclaiming this cultural heritage, including Anishnaabe legends, and, second, undertaking a spiritual journey beginning in Shamanism and later encompassing Christianity and Eckankar. The former establishes a link to the physical world, the latter an expression of spiritual dimensions; the two halves of a whole as defined and united by Morrisseau in his m work.

Norval Morrisseau: Shaman Artist, an exhibition at the National Gallery of Canada of 59 works (out of a considered 1500) covering the period I958-2002, takes the participant/ viewer on this transformative journey.
That Morrisseau is Aboriginal sets the context, but he is first and foremost an artist on an artist's journey, with a highly individual vision and style.

The spiritual journey is well-trod territory in the art world, but Morrisseau's work sings with freshness and poignancy as his style evolves from its birch bark beginnings, through to the use of more conventional materials and a concern for woodland tones, on to vibrant colours and huge canvases. He is one of the very few living artists who started a completely new art movement: the Woodland or Legend School, now called the Anishnaabe School, and has been dubbed the Father of Canadian Aboriginal Art. Morrisseau's distinctive style has influenced three generations of Aboriginal artists, including Carl Ray, Daphne Odjig, Jackson Beardy, Roy Thomas and the Kakegamic brothers, Goyce and Joshim, as well as the curator of this exhibit, Greg Hill, who is also an artist and member of the First Nations.

Much has been made of the fact that this is the first solo exhibit of an Aboriginal person's art in the history of the National Gallery of Canada. Morrisseau's work has been celebrated by Canadians since his inaugural solo exhibit sold out at Jack Pollock's gallery in Toronto back in 1962 , and he continues to be one of this country's most collected artists. Despite this popular acclaim, the National Gallery didn't own any of his work until 2000 (its first contemporary Aboriginal acquisition was in 1986). Before that his work was relegated to museums, primarily as a subject of ethnographic concern rather than artistic. This colonial holdover is all the more odious and blatant

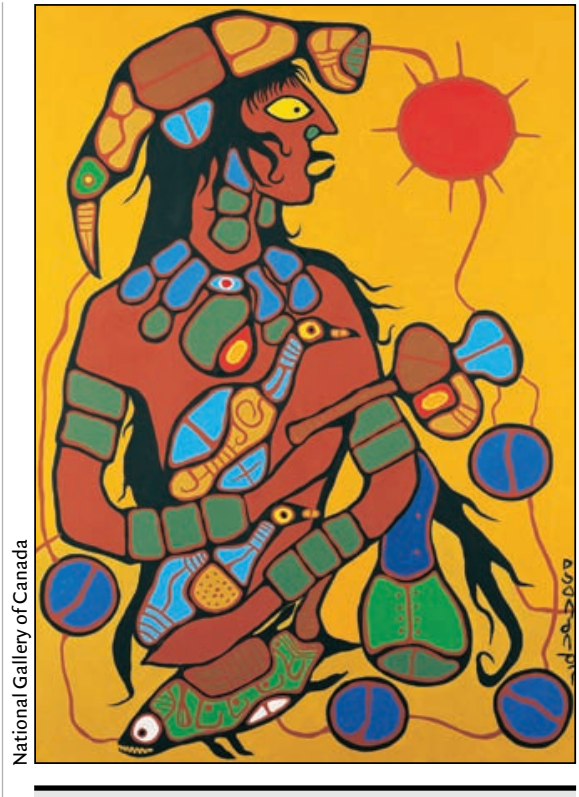

Norval Morrisseau, Man Changing into Thunderbird (panel one of 6) (1977). Acrylic on canvas. $153.5 \times 125.7$ $\mathrm{cm}$. Private Collection.

given the international acknowledgement of his place in the art world. In I989, he was I of only 3 Canadian artists to exhibit at the Centre Georges Pompidou in Paris as part of the French Revolution Bicentennial celebrations; the French press fêted him as the "Picasso of the North." Seventeen years after Paris, our national gallery has finally recognized Morrisseau as worthy of a solo show - arguably a breakthrough, in according full artistic status to First Nations people (aside from Inuit work) but shame on all of us for this inexcusable delay.

Not surprisingly, given his life's journey, there is an eerie uncertainty surrounding Morrisseau's place in the 
world from his birth onward: his birth date may be March I6 or I7, 1932, his birthplace may be Fort William (now Thunder Bay) or Beardmore or Sandy Lake Reserve, and although he was registered as Jean-Baptiste Norman Henry Morrisseau, he was known as Norval, per Thunderbird.

Perhaps it is this uncertainty, coupled with the influence of the grandparents who raised him (his grandfather was a Shaman, his grandmother a devout Catholic) that propelled him to look for meaning in the spiritual world. Morrisseau's journey has been fraught with difficulty. He endured sexual abuse at the Catholic residential school he briefly attended; a life-threatening but ill-defined illness cured by an Anishnaabe medicine woman (who bestowed on him the name (Copper Thunderbird); tuberculosis at age 26 ; horrific burns; alcohol and drug abuse; jail time; brief patronage from the mob; periods of extreme destitution, including living on the streets of Vancouver; and estrangement from his 7 children. Now in his 7os, he suffers from Parkinson's but has attained happiness and sobriety with his adopted family in Nanaimo, British Columbia.

Throughout it all he continued to paint a range of subjects, including erotica and representations of animals - some 6000 to ro ooo works in all and later reborn, after an illness, as Cop-

during his prodigious career. Hill chose to hang the Gallery exhibit on Morrisseau's Shaman/spiritual paintings because, as he told $C M A J$, they "tend to be the most powerful." Certainly, spirituality appears to be an abiding concern of the artist and the man. He left school after grade 4 and became preoccupied with oral culture and traditional shamanistic ritual practices that allow people to communicate and acquire blessings of power from other beings who inhabit the universe. His absorption in his culture and Shaman traditions set him apart, opening the way for transformations. Morrisseau is officially a Grand Shaman of the Ojibwa. He can enter a trance state, an ecstatic experience, that allows the soul to leave the body and see the world in ways unknown to earthbound denizens. He is not, however, a Shaman healer, except insofar as some people claim his work has healing properties, in particular the power of the colour he uses. Primarily, he is a "visual scribe documenting the shamanic 'ecstatic' experience,"” writes Hill. "Time has obscured the notion of the artist as visionary - imaging for others that which could only be imagined." Artist and Shaman "can be viewed as one and the same."

The journey - and exhibit chronicles this union.

Morrisseau was first discovered

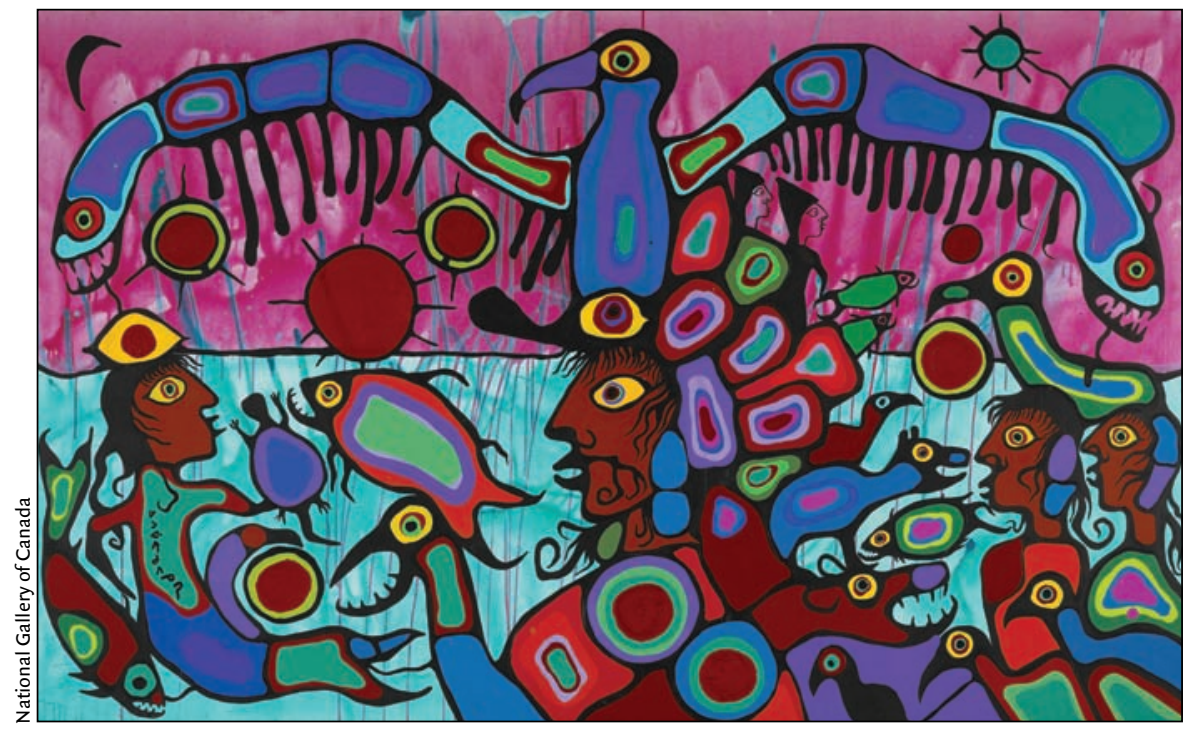

Norval Morrisseau, Artist and Shaman Between Two Worlds (1980). Acrylic on canvas.

$175 \times 282 \mathrm{~cm}$. The Klamer Family, Katonah, New York, USA outside the Aboriginal world in 1958 by the mining company physician and painter Dr. Joseph Weinstein and his wife Esther. They saw in Morrisseau's crafts, that he was selling door-todoor, the potential art. They bought him art supplies, gave him access to their extensive art library and, when Morrisseau began painting in I959, acquired some of his paintings.

The exhibit begins at this juncture in his life, with Morrisseau interpretations of important Anishnaabe legends and symbols, such as the medicine snake, mostly painted on unorthodox surfaces, including birch bark, roofing paper, cardboard and tar paper.

In I96I, anthropologist Selwyn Dewdney recognized Morrisseau's potential for using art to transmit his cultural knowledge and he began teaching him in materials and techniques. Dewdney encouraged Morrisseau to use earth tones reflective of the woodlands: 2 of Morrisseau's paintings of this time are the charming Untitled (Two Bull Moose) (1965) and Earth Mother (I966).

From the beginning, Morrisseau created a visual bridge from the culture of the Anishnaabe to art, in terms of subject matter and style. His pictographic style has its roots in the distinctive bead work of the Anishnaabe, where black rows of beads separate and delineate shapes such as the petals of a flower. He also had an early interest in colour, perhaps derived from the iconography of the Ojibway people in their traditional clothing, adornments, dyed porcupine quills and, later, glass beads.

To this Morrisseau added his own iconography. He reveals the souls of humans and animals through what has been simplistically termed an x-ray style of imaging. Sinewy black spirit lines emanate, surround and link the figures, while stylized skeletal elements and internal organs within the figures' segments represent their spirituality, as well as, sometimes, their physical strength (rigid bone structure) or health and vitality (enlarged heart of a bird). Dots denote power. Lines drawn out of people's mouths represent power or communication or establish relationships. An intersected circle expresses the idea of duality — night and day, men and women - 


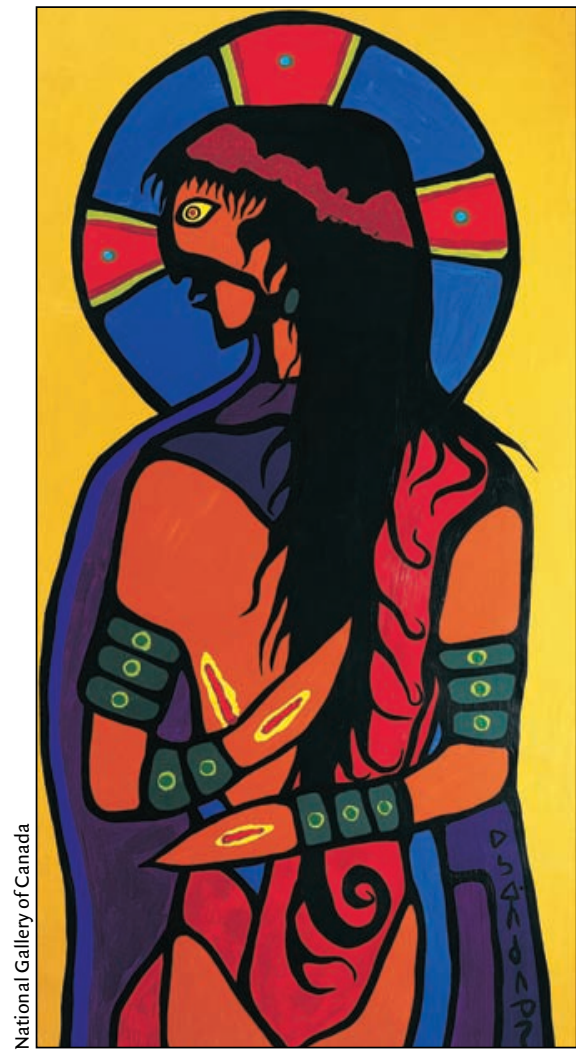

Norval Morrisseau, Indian Jesus Christ (1974). Acrylic on paper. $134.6 \times$ $68.5 \mathrm{~cm}$. Indian and Northern Affairs Canada, Gatineau, Quebec

and the concept of the necessity of two halves to balance the whole.

In I972, Morrisseau suffered serious burns to three-quarters of his body in a Vancouver hotel fire and reportedly had a vision of Jesus telling him to be a role model through his art. He converted to the apostolic faith, which is part of the Christian Fundamentalist movement, and he embarked on a spiritual path with works such as Indian Jesus Christ (1974), which challenges the missionary zeal to convert and the presumption that Aboriginals have to abandon their own culture to become Christian.

He was not reluctant to offer political comment either. In The Gift (I975), a dotted (powerful) missionary gives an Aboriginal adult and child dots smallpox, which wiped out about 90\% of Aboriginals in North America.

Around this time Morrisseau was introduced to Eckankar, a spiritual belief in the ability of the soul to exist and travel separately from the body and even the mind, and which leads to spiritual

\section{Poem}

\section{Death of a doctor}

Be the shade from sun on the snow covered road a white scar left where the basal cell was removed deep and rooted

Be the cut of the surgeon's knife the harbinger of news from tall places the bridge you stood on the night you thought

I could if then not now maybe be the long shadow that is lost in the dark in a prairie city on a uneasy March night

Gather the many white scars of stars in the backyard of your retinas They are the ones you can see

Your discontent feeds your memory The white ash is only the ash of another barkless tree without birds

Your hands hold open a new book They are not the hands that once pushed you To obey or not to obey

is your choice

is your choice

Your recall is excellent

You put on your white lab coat over the pressed striped shirt over the black pressed pants

You put on your polished black shoes You combed your hair across your forehead You pared your nails

You noticed the white in the nail beds It was telling you something You listened:

"Today is the day you risk everything to discover the last philosophy of yourself on this earth."

\section{Yvonne Trainer, PhD}

Faculty of Humanities

University of Alberta (Augustana Campus)

Camrose, Alta. 


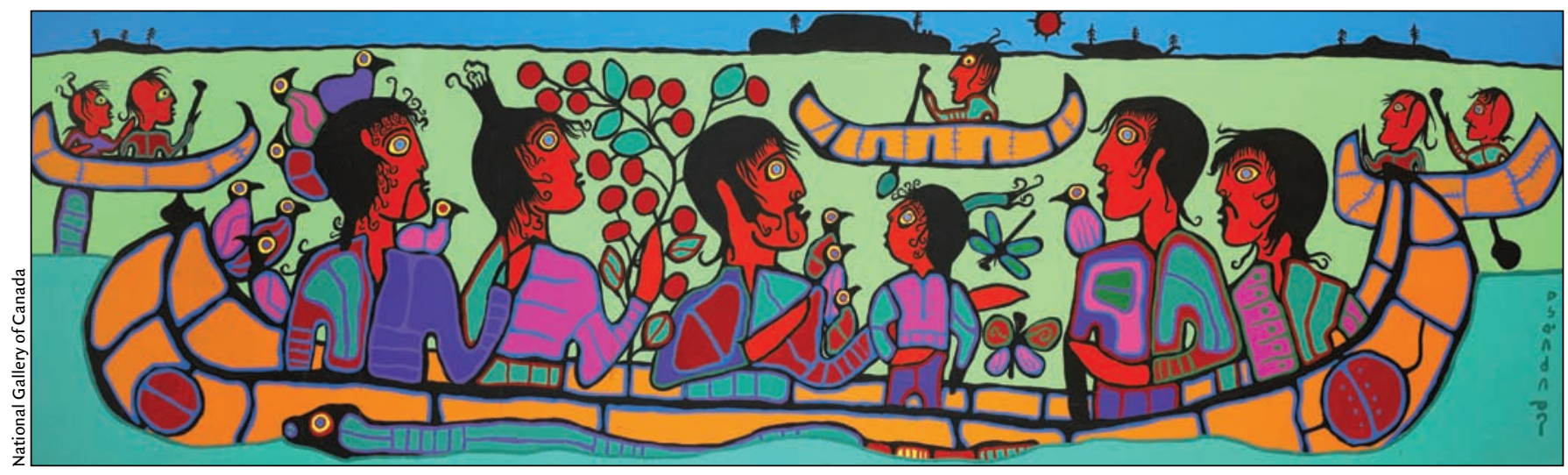

Norval Morrisseau, Untitled (Migration)(c. 1994). Acrylic on canvas. $139.8 \times 465 \mathrm{~cm}$. Collection of Gabe and Michele Vadas/Norval Morrisseau.

emancipation - a concept not dissimilar from the Shaman belief in soul travel. Morrisseau shifted away from Christianity and incorporated the ideal of the universality of the soul as he remade the ancient Aboriginal concepts. Eckankar is a religion of light and colour, with an emphasis on colour (particularly blue) in travelling to an astral plane or world. With this conversion came an electrifying explosion of colour in Morrisseau's art, which some claim has healing powers. In his diptych The Storyteller: the Artist and his Grandfather (1978) the word $\mathrm{Hu}$, an Eckankar chant practised to bring one's soul closer to God, is evident.

There are many other highlights, including the 6-panel painting Man Changing into Thunderbird (I977) and Artist and Shaman Between Two Worlds (I980), with its cross-cultural third eye. The masterpiece though, and high point of the exhibit, is the mammoth (366 × 6ro cm) Androgny (1983), which depicts a dream cosmology in vibrating colours, including new experiments with the blue light of energy.

By I987, Morrisseau was on the streets of Vancouver, grappling with alcohol, when he met Gabe Vadas, whom he now regards as his son. An enduring relationship and a kinder gentler time for Morrisseau began.

Despite suffering from Parkinson's disease, Morrisseau was able to hold a paint brush steady for many years. However, those days are over. Now he is reportedly turning to textiles and quilt-making may be his last artistic foray as he continues to link spirituality in ancient and modern forms, offering us a way to connect with our world.

Barbara Sibbald

CMAJ

\section{REFERENCES}

I. Frye N. The Bush Garden: Essays on Canadian Imagination. Toronto: House of Anansi Press; I97I. p. 220.
2. Hill G. Norval Morrisseau: Shaman Artist [exhibition catalogue]. Ottawa: National Gallery of Canada; 2006. p. 28

\section{Exhibition itinerary:}

Thunder Bay Art Gallery, Thunder Bay, Ont., June 3-Sept. 4, 2006; The McMichael Canadian Art Collection, Kleinberg, Ont., Sept. 30-Jan. 14, 2007; National Museum of the American Indian, New York City, Oct. 6, 2007-Jan. 6, 2008

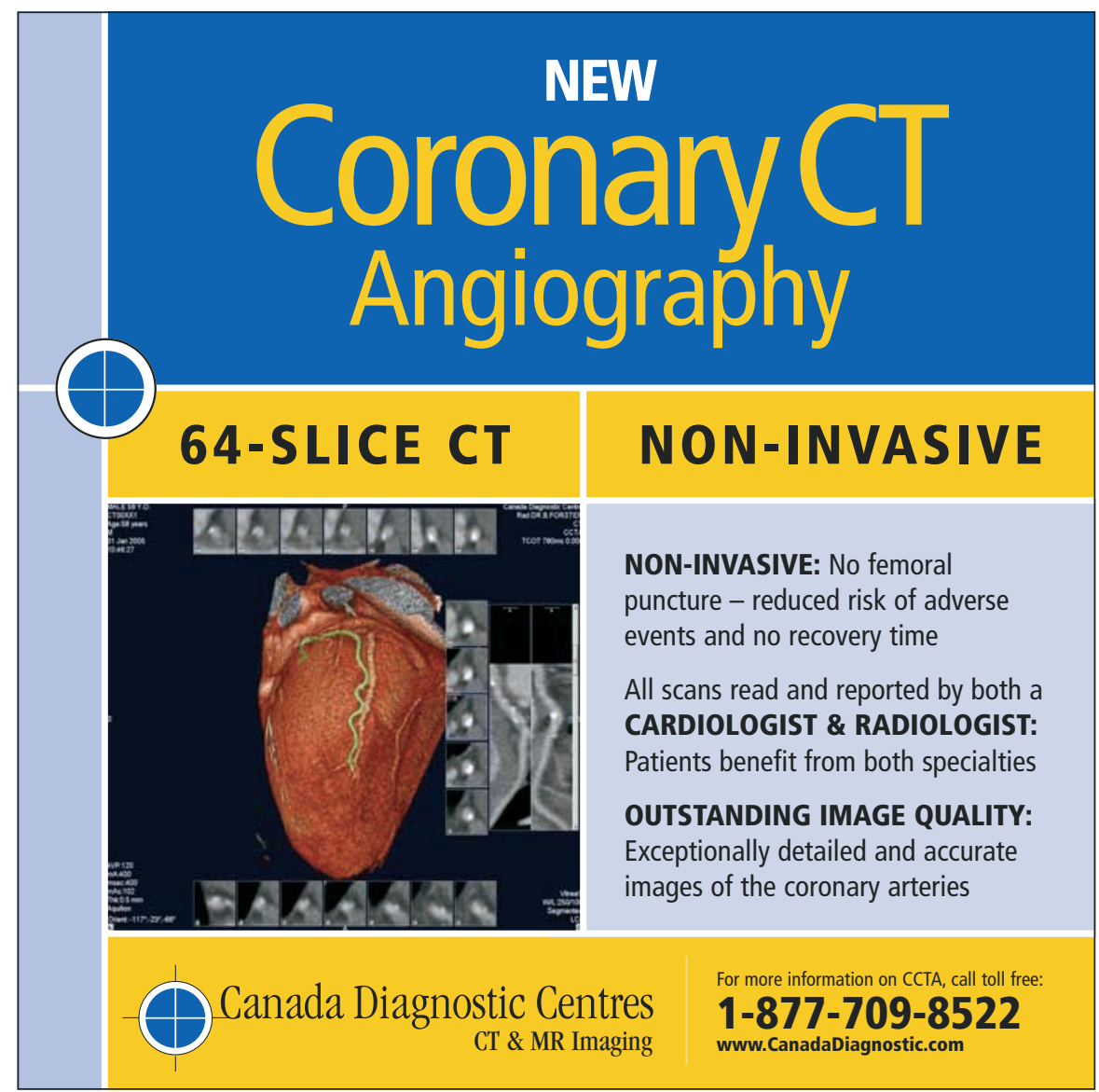

